\title{
Effect of Audiovisual Modeling on 5-10-year-old Children's Anxiety and Cooperation Behavior in First and Second Dental Visits
}

\author{
${ }^{1}$ Nabila A Sedky, ${ }^{2}$ Aseel H Al Hasson
}

\begin{abstract}
Objectives: Assessing the effect of audiovisual modeling distraction on anxiety and cooperation behavior in 1st and 2nd dental visits of Saudi children aged 5-10 year-old in Qassim province.
\end{abstract}

Materials and methods: Randomized controlled clinical trial conducted at College of Dentistry, Qassim University. After exclusion of nonconformity cases, sample size consisted of 98 patients distributed equally to test and control groups based on children's anxiety level. Quantification of children's behavior was based on Venham Scale for anxiety level and behavior rating scale was based on Frankle scale. Ratings were performed by a dentist other than the treating dentist and who was blinded on study procedure. Statistical analyses were carried out at a significance level of $<0.05$ and 0.01 .

Results: No statistical difference was detected for children in Group I (without audiovisual modeling) during their 1st and 2nd visits for anxiety and cooperation scales $(p=0.855$ and 0.787 , respectively). For group II (before and after audiovisual modeling), a statistically significant difference was found in anxiety and cooperation levels of children in the $2 \mathrm{nd}$ visit in relation to 1 st visit ( $p=0.010$ and 0.000 , respectively). Regarding studied groups in the 2 nd visit, a statistically significant difference was found in group II as children who were watching the cartoon film in the 2 nd visit before any dental treatment were less anxious and more cooperative with the dentist $(p=0.004$ and 0.000 , respectively).

Conclusion: Audiovisual modeling in the form of a film/video is successful in reducing disruptive behavior in children during their dental treatment producing a less anxious and more cooperative patient.

Keywords: Anxiety and behavior, Audiovisual modeling, Frankle Scale, Randomized controlled clinical trial, Venham scale.

How to cite this article: Sedky NA, Hasson AHA. Effect of Audiovisual Modeling on 5-10-year-old Children's Anxiety and Cooperation Behavior in First and Second Dental Visits. Int J Experiment Dent Sci 2018;7(2):54-62.

\footnotetext{
${ }^{1}$ Associate Professor, ${ }^{2}$ Dental Intern

${ }^{1}$ Department of Community Dentistry and Oral Epidemiology, College of Dentistry, Qassim University, Buraidah, Saudi Arabia

${ }^{2}$ Department of Community Dentistry, College of Dentistry, Qassim University, Buraidah, Qassim, Saudi Arabia

Corresponding Author: Nabila A Sedky, Associate Professor, Department of Community Dentistry and Oral Epidemiology, College of Dentistry, Qassim University, Buraidah, Saudi Arabia, e-mail: nasedky@yahoo.com
}

\section{Source of support: Nil}

Conflict of interest: None

\section{INTRODUCTION}

Anxiety has been defined as a state of imprecise fearfulness towards a specific condition that does not essentially have previous experience.

Dental anxiety and the avoidance of circumstances that include dental treatment and healthcare have commonly been assumed to be the source of serious oral health problems in children and adults. ${ }^{1}$ High levels of anxiety avoid a patient from fully cooperating with the dentist, which can result in time wasting for the dentist and unnecessary difficulties during treatment implementation and, most importantly, can restrict the effectiveness of the dental treatment and avoid the early detection of pathological conditions. ${ }^{2}$ It was precisely recognized that children with higher levels of dental anxiety have a greater number of untreated carious teeth. Thus, dental anxiety might affect the quality of dental care that a patient receives. Furthermore, the treatment of anxious patients is one of the most stressful aspects to the dentists during performing their works. ${ }^{3-5}$ It was found that many professionals consider children who reveal uncooperative behavior to be one of the utmost difficulties in dental practice. ${ }^{3}$ Given that there is a connection between dental anxiety and uncooperative behavior, it is important for dentists to be able to assess anxiety in their patients, this is to determine who are in need for special care concerning their fear. ${ }^{6,7}$

Providing effective dental treatment to a child patient necessitates thorough knowledge to identify dental Anxiety and cooperation behavior and its management by the application of techniques concerned with behavioral management. ${ }^{8}$ Taking into consideration these concerns, a dentist who does not focus on the psychological needs of a child will immediately be challenged by an uncooperative patient. ${ }^{9}$ In 1990, Pinkham et al. ${ }^{10}$ indicated that management of behavior is as fundamental as dexterity and knowledge of the material to be used which is essential for clinical success in pediatric dentistry. ${ }^{10}$ Likewise, a study was carried out by Wright in $1983^{11}$ 
revealed that every dental team should keep two main points in mind that they should carry out dental treatment effectively and efficiently as well as encourage a positive attitude in the child. ${ }^{11}$

Modeling belongs to learning by observation and children may repeat behavior displayed by the model in a similar situation. It was expressed by Bandura in $1968^{12}$ as a procedure which can decrease children's fear and avoidance behavior. ${ }^{12,13}$ Modeling can be implemented in two forms: live or filmed one. Studies on modeling have revealed its therapeutic effect in the management of anxiety ${ }^{14,15}$ and educational effect in enhancing the coping skills of children in medical stressful situations. ${ }^{16}$

The first dental visit is fundamental in the construction of the child's attitude with regard to dentistry and the success of future treatment. The technique of "Tell Show Do" is frequently applied by pediatric dentists in the management of children's anxiety at a pretreatment visit. It determines that before anything is done, the child be told what will be done and then shown by some simulation exactly what will happen before the procedure is started. The technique of "Tell Show Do" is performed by the dentists themselves in the operatory room, and is based on the principle of learning theory. ${ }^{13,17}$

It has been proposed to practice the live or filmed modeling technique as an effective intervention to prepare the child for a dental visit. ${ }^{18}$ Live models such as parents, peers or relatives are used for pre-appointment teaching of the predictable behavior to the child patient. ${ }^{19-21}$ Several studies have assessed the effectiveness of the modeling through a film in the reduction of child's dental anxiety. ${ }^{22-28}$ It has been revealed that filmed modeling can be effective as well as live modeling in addition to desensitization methods. ${ }^{22,24}$ In contrast to the other social learning based methods, filmed modeling does not take time by the dentist and the dental team although it has not achieved its appropriate situation. ${ }^{18}$

In 2013, Mungara et al. ${ }^{29}$ studied the dental fear of the pediatric patients between 5 years-old and 9 years-old, the researchers found that the most fear aggravating stimulus for the studied children was injection and the least was to open the mouth and having someone look at them. ${ }^{29}$

With this background, this study was undertaken to assess the effect of audiovisual modeling distraction on anxiety and cooperation behavior in the first and second dental visits of Saudi children aged 5-10 years-old in Qassim province. The results obtained would serve as baseline data for planning a treatment modality aimed at the minimization of preoperative anxiety and fear for children to fully cooperate in dental visits and enabling them to receive better dental treatment.

\section{MATERIAL AND METHODS}

A randomized controlled clinical trial (RCT) was conducted and completed at the Department of Ortho and Pediatric Dentistry, College of Dentistry, Qassim University, Kingdom of Saudi Arabia, between June 2016 and March 2017, after obtaining approval from the Ethics Committee of the Dental Research Center of Qassim University. A total of 150 pediatric patients aged 5 to 10 years (mean age $=7.33$ years, $\mathrm{SD}=+1.62$ years) requiring a dental treatment were recruited for this study. Some criteria were taken into account in this study, the inclusion criteria were:

- The absence of any systemic diseases and hospitalization.

- The absence of any psychiatric disorders, anxiety, and history of social or specific phobia for any reason.

- The absence of previous bad dental experience.

- Not having experienced any harmful accidents like (severe accidents, abduction, eye-witnessing a crime, sexual abuse, and physical abuse).

- The absence of any psychopathological familial history including divorce, familial violence, and child abuse.

Prior to starting any visit and after being disclosed the nature of the study, the parents were asked to sign an informed consent form to approve the participation in the study as well as a questionnaire covering the parents' and children's demographic and social information.

In the treatment room, the mother sat down and was asked not to talk neither to the child nor to the dentist and also not to intervene in any form in case of her child was not cooperative. A video camera was located on the top of the dental unit light pole after being hidden from view and was focused on the child's head and hands to record child's behavior during the 1st and 2nd visits.

At the first visit, before splitting the groups, the dentist started with asking the child his/her name and age; then the dentist tried to manage child's behavior by Tell-ShowDo technique and all children were subjected to just a diagnosis, prophylaxis with paste and rubber cup as well as fluoride therapy to increase their familiarity with dental procedures. At the end of the first visit, the necessary evaluations were prescribed for the child's anxiety ${ }^{30}$ and cooperation. ${ }^{31}$ Out of the 150 children who completed the first visit, and after the exclusion of nonconformity cases, the sample size consisted of 98 pediatric patients distributed as follows based on children's anxiety level (Venham scaling rate): ${ }^{30}$

Score (0) relaxed: $10(20.41 \%)$ children

Score (1) uneasy: 26 (53.06\%) children

Score (2) tense: 16 (32.65\%) children 
Score (3) reluctant: 32 (65.31\%) children

Score (4) interference: $12(24.49 \%)$ children

Score (5) out of contact: $2(4.08 \%)$ children

The selected children were randomly allocated into two equal groups (test and control groups) by a stratified sampling technique based on Venham scaling rate. The first group (group I), included those children treated without any audiovisual modeling (control group); while the second group (group II), included the children treated with the audiovisual modeling (test group). Then the date of the second visit was set for one week later for both groups.

In the second visit, following describing what the child had to undergo for the dental treatment explained in a simple and easy-to-understand method, the required modality of treatment was performed. Similar treatments were tried to be included for all children. The majority of children received treatments in the form of pulpotomy for deciduous molars followed by application of stainless steel crowns, and some of them received restorative treatment in the form of amalgam and composite filling restorations, and the minority of the participants need extraction. It should be noted that the treatment procedures in both groups followed a normal distribution. Group I received their treatment without any audiovisual intervention, while group II obtained their dental treatment after watching a cartoon film aimed at teaching the child how to perform dental care (the film displayed the same procedure consisting of Tell-Show-Do, prophylaxis with paste and rubber cup as well as fluoride therapy on a similar age as the studied age group) and how much damage caused as a result of the negligence of dental care. The produced film had been approved by three

Table 1: Venham 6-point Index to obtain anxiety level

\begin{tabular}{|c|c|}
\hline Rating & Description \\
\hline 0 & $\begin{array}{l}\text { Relaxed: Smiling, willing, able to converse, } \\
\text { displays behavior desired by the dentist. }\end{array}$ \\
\hline 1 & $\begin{array}{l}\text { Uneasy: Concerned, may protest briefly to } \\
\text { indicate discomfort, hands remain down or } \\
\text { partially raised. Tense facial expression, 'high } \\
\text { chest'. Capable of cooperating. }\end{array}$ \\
\hline 2 & $\begin{array}{l}\text { Tense: Tone of voice, questions and answers } \\
\text { reflect anxiety. During stressful procedure, } \\
\text { verbal protest, crying, hands tense and raised, } \\
\text { but not interfering very much. Protest more } \\
\text { distracting and troublesome. Child still complies } \\
\text { with request to cooperate. }\end{array}$ \\
\hline 3 & $\begin{array}{l}\text { Reluctant: Pronounced verbal protest, } \\
\text { crying. Using hands to try to stop procedure. } \\
\text { Treatment proceeds with difficulty. }\end{array}$ \\
\hline 4 & $\begin{array}{l}\text { Interference: General crying, body movements } \\
\text { sometimes needing physical restraint. Protest } \\
\text { disrupts procedure. }\end{array}$ \\
\hline 5 & $\begin{array}{l}\text { Out of contact: Hard loud swearing, screaming } \\
\text { unable to listen, trying to escape. Physical } \\
\text { restraint required. }\end{array}$ \\
\hline
\end{tabular}

pediatric dentists and movie, in general, was exciting for the children because it was designed specifically for this age group.

In both sessions and for all children, all parameters in the form of the attending dentist, dental assistant, the working environment, time and duration of the appointment (30 minutes for each child), and the type of dialogues were constant. It was taken into consideration the children's general condition as they should not be tired, hungry nor having any disease; also the session was scheduled in the afternoon, not during the school time and activity time of the child.

The quantification of the children's behavior was based on Venham scale for anxiety level, ${ }^{30,32}$ (Table 1), and a behavior rating scale was based on the Frankel scale, ${ }^{31}$ (Table 2). The ratings were performed by inspecting the recorded camera videos for the participating children by a dentist other than the dentist who was treating the patients and who was blinded on the study procedure.

\section{Statistical Analysis}

Statistical analysis was conducted using the statistical package for social sciences program (SPSS 22.0 for Windows, SPSS Inc., Chicago, USA). All statistical analyses were carried out at a significance level less than 0.05 and 0.01 . The data were analyzed and subjected to descriptive statistics like frequencies, percentages, cross-tabulation, means, and standard deviations. Paired samples t-test was used to investigate associations between variables in each group before and after intervention (audiovisual's presence/absence) and finally, Independent samples t-test was employed to investigate the effect on the studied groups after intervention.

\section{RESULTS}

In the current study, out of the 150 children who were screened and completed the 1st visit only 98 children met the research criteria. So, the final sample constituted 98

Table 2: Frankle 4-point Index to obtain cooperation level

\begin{tabular}{ll}
\hline Rating & Description \\
\hline 1 & $\begin{array}{l}\text { Definitely negative: Refusal of treatment, crying } \\
\text { forcefully, fearful, or any other overt evidence of } \\
\text { extreme negativism }\end{array}$ \\
2 & $\begin{array}{l}\text { Negative: Reluctant to accept treatment, } \\
\text { uncooperative, some evidence of negative attitude but } \\
\text { not pronounced, sullen, withdrawn }\end{array}$ \\
& $\begin{array}{l}\text { Positive: Acceptance of treatment, at times cautious, } \\
\text { willingness to comply with the dentist, at times with } \\
\text { reservation but patient follows the dentist's directions } \\
\text { cooperatively. } \\
\text { Definitely positive: Good rapport with the dentist, } \\
\text { interested in the dental procedures, laughing and } \\
\text { enjoying the situation }\end{array}$ \\
\hline
\end{tabular}


Table 3: Relation between group I in the 1st and 2nd visits (without audiovisual modeling) and anxiety as well as cooperation levels $(\mathrm{N}=49)$

\begin{tabular}{|c|c|c|c|c|c|c|c|c|}
\hline \multirow{6}{*}{$\begin{array}{l}\text { Group I } \\
\text { 1st visit } \\
\text { (without audiovisual modeling) } \\
\text { Group I } \\
\text { 2nd visit (without audiovisual } \\
\text { modeling) }\end{array}$} & \multirow[b]{3}{*}{ Count } & \multicolumn{6}{|c|}{ Venham scaling rate (anxiety level) group I } & \multirow{2}{*}{$\begin{array}{l}x^{2} \\
(p)\end{array}$} \\
\hline & & \multirow{2}{*}{$\begin{array}{l}\text { Relaxed } \\
5\end{array}$} & \multirow{2}{*}{$\frac{\text { Uneasy }}{13}$} & \multirow{2}{*}{$\begin{array}{l}\text { Tense } \\
8\end{array}$} & \multirow{2}{*}{$\frac{\text { Reluctant }}{16}$} & \multirow{2}{*}{$\begin{array}{l}\text { Interference } \\
6\end{array}$} & Out of contact & \\
\hline & & & & & & & 11 & \multirow{4}{*}{$\begin{array}{l}1.958^{*} \\
(0.855)\end{array}$} \\
\hline & $\%$ within group I & $10.20 \%$ & $26.53 \%$ & $16.33 \%$ & $32.65 \%$ & $12.24 \%$ & $2.04 \%$ & \\
\hline & Count & 4 & 14 & 12 & 12 & 5 & 2 & \\
\hline & $\%$ within group I & $8.16 \%$ & $28.57 \%$ & $24.49 \%$ & $24.49 \%$ & $10.20 \%$ & $4.08 \%$ & \\
\hline \multirow{6}{*}{$\begin{array}{l}\text { Group I } \\
\text { 1st visit } \\
\text { (without audiovisual modeling) } \\
\text { Group I } \\
\text { 2nd visit } \\
\text { (without audiovisual modeling) }\end{array}$} & & \multicolumn{6}{|c|}{ Frankle scaling rate (cooperation level) group I } & \multirow{6}{*}{$\begin{array}{l}x^{2} \\
(p)\end{array}$} \\
\hline & \multirow{3}{*}{$\begin{array}{l}\text { Count } \\
\% \text { within group I }\end{array}$} & \multicolumn{2}{|c|}{ Definitely negative } & Negative & Positive & \multicolumn{2}{|c|}{ Definitely positive } & \\
\hline & & \multicolumn{2}{|c|}{7} & 19 & 16 & \multicolumn{2}{|c|}{7} & \\
\hline & & \multicolumn{2}{|l|}{$14.29 \%$} & $38.78 \%$ & $32.65 \%$ & \multicolumn{2}{|l|}{$14.29 \%$} & \\
\hline & Count & \multicolumn{2}{|l|}{8} & 15 & 20 & \multicolumn{2}{|l|}{6} & \\
\hline & $\%$ within group I & \multicolumn{2}{|l|}{$16.33 \%$} & $30.61 \%$ & $40.82 \%$ & \multicolumn{2}{|l|}{$12.24 \%$} & \\
\hline
\end{tabular}

${ }^{* *} p<0.01,{ }^{*} p<0.05$

children, 56 girls and 42 boys ( $57.1 \%$ and $42.9 \%$, respectively), with a mean age of 7.33 years ( $\mathrm{SD}=+1.62$ years).

Table 3 reveals the relation between group I in the 1st and 2nd visits (without audiovisual modeling) and anxiety as well as cooperation levels. No statistical difference was detected for children in Group I during their 1st and 2nd dental visits neither for the anxiety nor for the cooperation scales $(2=1.958, p=0.855$, and $2=1.059$, $p=0.787$, respectively).

On the other hand, and with regard to the children in Group II both in 1st and 2nd visits (before and after audiovisual modeling), a statistically significant difference was found in the anxiety level as well as in the cooperation level of children who had been exposed to watch the video prior to the second treatment session where $36.73 \%$ of children recorded score (0) in Venham scaling rate meaning that they were "relaxed" in 2nd visit in relation to only $10.20 \%$ in the 1 st visit $\left(2=15.208^{*}\right.$, $p=0.010)$, and $57.14 \%$ of the participating children were found to be "definitely positive" to cooperation with the dentist during the 2 nd dental visit and after watching the video compared to just $14.29 \%$ in the 1 st visit $\left(2=23.451^{*}\right.$, $p=0.000)$, (Table 4).

Table 5 portrays the relationship between the studied groups (groups I and II) during their 2nd dental visit without and with the intervention with audiovisual modeling and anxiety as well as cooperation levels. A statistically significant difference was detected in group II with regard to anxiety and cooperation levels where the children who were watching the cartoon film in the 2nd visit prior to any dental treatment were less anxious and more cooperative with the dentist than their counterparts who received their dental treatment without any audiovisual intervention $\left(2=17.479^{*}, p=0.004\right.$ and $2=$ $25.811^{*}, p=0.000$, respectively).

Table 6 depicts the association between children in group I during their 1st and 2nd visits without intervention and those in group II in 1st and 2nd visits without

Table 4: Relation between group II in the 1st and 2nd visits (before and after audiovisual modeling) and anxiety as well as cooperation levels $(\mathrm{N}=49)$

\begin{tabular}{|c|c|c|c|c|c|c|c|c|}
\hline & & \multicolumn{6}{|c|}{ Venham scaling rate (anxiety level) group II } & \multirow{2}{*}{$\begin{array}{l}x^{2} \\
(P)\end{array}$} \\
\hline & & Relaxed & Uneasy & Tense & Reluctant & Interference & Out of contact & \\
\hline \multirow{6}{*}{$\begin{array}{l}\text { Group II } \\
\text { 1st visit } \\
\text { (before video) } \\
\text { Group II } \\
\text { 2nd Visit } \\
\text { (after video) }\end{array}$} & Count & 5 & 13 & 8 & 16 & 6 & 1 & \multirow{4}{*}{$\begin{array}{l}15.208 * \\
(0.010)\end{array}$} \\
\hline & $\%$ within group II & $10.20 \%$ & $26.53 \%$ & $16.33 \%$ & $32.65 \%$ & $12.24 \%$ & $2.04 \%$ & \\
\hline & Count & 18 & 17 & 7 & 5 & 1 & 1 & \\
\hline & \% within group II & $36.73 \%$ & $34.69 \%$ & $14.29 \%$ & $10.20 \%$ & $2.04 \%$ & $2.04 \%$ & \\
\hline & & \multicolumn{6}{|c|}{ Frankle scaling rate (cooperation level) group II } & \multirow{2}{*}{$\begin{array}{l}x^{2} \\
(P)\end{array}$} \\
\hline & & Definitely & ative & Negative & Positive & Definitely po & tive & \\
\hline \multirow{2}{*}{$\begin{array}{l}\text { Group II } \\
\text { 1st visit } \\
\text { (before video) }\end{array}$} & Count & 7 & & 20 & 15 & 7 & & \multirow{4}{*}{$\begin{array}{l}23.451^{\text {** }} \\
(0.000)\end{array}$} \\
\hline & $\%$ within group II & $14.29 \%$ & & $40.82 \%$ & $36.61 \%$ & $14.29 \%$ & & \\
\hline \multirow{2}{*}{$\begin{array}{l}\text { Group II } \\
\text { 2nd visit } \\
\text { (after video) }\end{array}$} & Count & 1 & & 9 & 11 & 28 & & \\
\hline & $\%$ within group II & $2.04 \%$ & & $18.37 \%$ & $22.45 \%$ & $57.14 \%$ & & \\
\hline
\end{tabular}

${ }^{* *} p<0.01,{ }^{*} p<0.05$ 
Table 5: Relation between group I and group II in the 2nd visit (without and with audiovisual modeling) and anxiety as well as cooperation levels $(N=98)$

\begin{tabular}{|c|c|c|c|c|c|c|c|c|}
\hline & \multicolumn{6}{|c|}{ Venham scaling rate (anxiety level) } & \multirow{2}{*}{$\begin{array}{l}x^{2} \\
(p)\end{array}$} \\
\hline & & Relaxed & Uneasy & Tense & Reluctant & Interference & Out of contact & \\
\hline \multirow{2}{*}{$\begin{array}{l}\text { Group I 2nd visit } \\
\text { without video }\end{array}$} & Count & 4 & 14 & 12 & 12 & 5 & 2 & \multirow{4}{*}{$\begin{array}{l}17.479 * \\
(0.004)\end{array}$} \\
\hline & $\%$ within 2 nd visit & $8.2 \%$ & $28.6 \%$ & $24.5 \%$ & $24.5 \%$ & $10.2 \%$ & $4.1 \%$ & \\
\hline \multirow{4}{*}{$\begin{array}{l}\text { Group II 2nd visit with } \\
\text { video }\end{array}$} & Count & 18 & 17 & 7 & 5 & 1 & 1 & \\
\hline & $\%$ within 2 nd visit & $36.7 \%$ & $34.7 \%$ & $14.3 \%$ & $10.2 \%$ & $2.0 \%$ & $2.0 \%$ & \\
\hline & & \multicolumn{6}{|c|}{ Frankle scaling rate (cooperation level) } & \multirow{2}{*}{$\begin{array}{l}x^{2} \\
(p)\end{array}$} \\
\hline & & Definitely & negative & Negative & Positive & Definitely po & itive & \\
\hline \multirow{2}{*}{$\begin{array}{l}\text { Group I 2nd visit } \\
\text { without video }\end{array}$} & Count & 8 & & 15 & 20 & 6 & & \multirow{4}{*}{$\begin{array}{l}25.811^{* *} \\
(0.000)\end{array}$} \\
\hline & $\%$ within 2 nd visit & $16.3 \%$ & & $30.6 \%$ & $40.8 \%$ & $12.2 \%$ & & \\
\hline \multirow{2}{*}{$\begin{array}{l}\text { Group II 2nd visit with } \\
\text { video }\end{array}$} & Count & 1 & & 9 & 11 & 28 & & \\
\hline & $\%$ within 2 nd visit & $2.0 \%$ & & $18.4 \%$ & $22.4 \%$ & $57.1 \%$ & & \\
\hline
\end{tabular}

${ }^{* *} p<0.01,{ }^{*} p<0.05$

and with intervention. No statistical difference was found in the 2nd visit of group 1 participants in relation to their 1 st visit with regard to their anxiety level and cooperation with the dentist (Venham scaling rate paired t-test $=0.771, p=0.444$ and Frankle scaling rate paired $\mathrm{t}$-test $=-0.256, p=0.799$ ). Conversely, regarding group II participants, less anxiety and more cooperation was reported among children comparing their scores in their 2nd visit with that of the 1st visit, where a statistically significant difference was registered between both visits (Venham scaling rate paired t-test $=5.815^{*}, p=0.000$ and Frankle scaling rate paired t-test $=-5.441^{*}, p=0.000$ ).

Furthermore, results in Table 7 demonstrated that the intervention had a positive effect on the participating pedi- atric patients where a statistically significant difference was reported among both studied groups in their 2nd dental visit, as the children who were exposed to watching the video were significantly less anxious and more cooperative with their dentist than their counterparts who didn't see any videos (Venham scaling rate Independent samples $\mathrm{t}$-test $=3.979^{*}, p=0.000$ and Frankle scaling rate independent samples t-test $=-4.789^{*}, p=0.000$ ).

\section{DISCUSSION}

Uncooperative behavior and anxiety in patients are still identified to be among the most considerable problems in pediatric dentistry, ${ }^{33,34}$ so detecting and assessing dental

Table 6: Paired t-test for group I in 1st and 2nd visits without audiovisual modeling and for group II in 1st and 2nd visits without and with audiovisual modeling

\begin{tabular}{|c|c|c|c|c|c|c|c|c|c|c|c|}
\hline \multirow{3}{*}{\multicolumn{2}{|c|}{$\begin{array}{l}\text { Group I } \\
\text { (without audiovisual modeling) }\end{array}$}} & \multicolumn{5}{|c|}{ Paired differences } & \multirow{3}{*}{$t$} & \multirow{3}{*}{$d f$} & \multirow{3}{*}{$\begin{array}{l}\text { Sig. } \\
\text { (2-tailed) }\end{array}$} & \multirow{3}{*}{ Group I } & \multirow{3}{*}{$N(+S D)$} \\
\hline & & \multirow[t]{2}{*}{ Mean } & \multirow[t]{2}{*}{$S D$} & \multirow{2}{*}{$\begin{array}{l}\text { Std. } \\
\text { error } \\
\text { mean }\end{array}$} & \multicolumn{2}{|c|}{$\begin{array}{l}95 \% \text { confidence } \\
\text { interval of the } \\
\text { difference }\end{array}$} & & & & & \\
\hline & & & & & Lower & Upper & & & & & \\
\hline \multirow{2}{*}{$\begin{array}{l}\text { Pair } 1 \\
(N=49)\end{array}$} & \multirow{2}{*}{$\begin{array}{l}\text { Venham scaling rate } 1 \text { st } \\
\text { visit-Venham scaling } \\
\text { rate } 2 \text { nd visit }\end{array}$} & 0.061 & 0.556 & 0.079 & -0.098 & 0.221 & 0.771 & 48 & 0.444 & 1st visit & $2.18(+1.333)$ \\
\hline & & & & & & & & & & 2nd visit & $2.12(+1.285)$ \\
\hline \multirow{2}{*}{$\begin{array}{l}\text { Pair } 2 \\
(N=49)\end{array}$} & \multirow{2}{*}{$\begin{array}{l}\text { Frankle scaling rate 1st } \\
\text { Visit-Frankle scaling } \\
\text { rate } 2 \text { nd Visit }\end{array}$} & -0.020 & 0.559 & 0.080 & -0.181 & 0.140 & -0.256 & 48 & 0.799 & 1st visit & $2.47(+0.915)$ \\
\hline & & & & & & & & & & 2nd visit & $2.49(+0.916)$ \\
\hline \multirow{3}{*}{\multicolumn{2}{|c|}{$\begin{array}{l}\text { Group II } \\
\text { (without and with audiovisual } \\
\text { modeling) }\end{array}$}} & \multicolumn{5}{|c|}{ Paired differences } & & \multirow{3}{*}{$d f$} & \multirow{3}{*}{$\begin{array}{l}\text { Sig. } \\
\text { (2-tailed) }\end{array}$} & \multirow{3}{*}{ Group II } & \multirow{3}{*}{$N(+S D)$} \\
\hline & & \multirow[t]{2}{*}{ Mean } & \multirow[t]{2}{*}{$\begin{array}{l}\text { Std. } \\
\text { deviation }\end{array}$} & \multirow[t]{2}{*}{$\begin{array}{l}\text { Std. } \\
\text { error } \\
\text { mean }\end{array}$} & \multicolumn{2}{|c|}{$\begin{array}{l}95 \% \text { confidence } \\
\text { interval of the } \\
\text { difference }\end{array}$} & $t$ & & & & \\
\hline & & & & & Lower & Upper & & & & & \\
\hline \multirow{2}{*}{$\begin{array}{l}\text { Pair } 1 \\
(N=49)\end{array}$} & \multirow{2}{*}{$\begin{array}{l}\text { Venham scaling rate 1st } \\
\text { visit-Venham scaling } \\
\text { rate } 2 \text { nd visit }\end{array}$} & \multirow{2}{*}{0.977} & \multirow{2}{*}{0.884} & \multirow{2}{*}{0.126} & \multirow{2}{*}{0.481} & \multirow{2}{*}{0.989} & \multirow{2}{*}{$5.815^{*}$} & \multirow{2}{*}{48} & \multirow{2}{*}{0.000} & 1st visit & $2.11(+1.242)$ \\
\hline & & & & & & & & & & 2nd visit & $1.12(+1.201)$ \\
\hline \multirow{2}{*}{$\begin{array}{l}\text { Pair } 2 \\
(N=49)\end{array}$} & $\begin{array}{l}\text { Frankle scaling rate } 1 \text { st } \\
\text { visit-Frankle scaling }\end{array}$ & -0.835 & 0.709 & 0.101 & -0.755 & -0.347 & $-5.441^{* *}$ & 48 & 0.000 & 1st visit & $2.51(+1.000)$ \\
\hline & rate 2 nd visit & & & & & & & & & 2nd visit & $3.35(+0.855)$ \\
\hline
\end{tabular}

${ }^{* *} p<0.01,{ }^{*} p<0.05$ 
Table 7: Independent samples test for group I and group II in 2nd visit (without and with audiovisual modeling) and anxiety as well as cooperation levels $(N=98)$

\begin{tabular}{|c|c|c|c|c|c|c|c|c|c|c|c|c|}
\hline \multirow{5}{*}{$\begin{array}{l}\text { Venham } \\
\text { scaling rate } \\
\text { (anxiety } \\
\text { level) }\end{array}$} & \multirow{5}{*}{$\begin{array}{l}\text { Equal } \\
\text { variances } \\
\text { assumed } \\
\text { equal } \\
\text { variances not } \\
\text { assumed }\end{array}$} & \multicolumn{9}{|c|}{$\begin{array}{l}\text { Levene's test } \\
\text { for equality of t-test for equality of means } \\
\text { variances }\end{array}$} & \multirow{3}{*}{$\begin{array}{l}\text { Group } \\
\text { statistics }\end{array}$} & \multirow{3}{*}{$\begin{array}{l}\text { Mean } \\
(+S D)\end{array}$} \\
\hline & & \multirow[t]{2}{*}{$\mathrm{F}$} & \multirow[t]{2}{*}{ Sig. } & \multirow[t]{2}{*}{$\mathrm{t}$} & \multirow[t]{2}{*}{$d f$} & \multirow[t]{2}{*}{$\begin{array}{l}\text { Sig. } \\
\text { (2-tailed) }\end{array}$} & \multirow{2}{*}{$\begin{array}{l}\text { Mean } \\
\text { diffe- } \\
\text { rence }\end{array}$} & \multirow{2}{*}{$\begin{array}{l}\text { Std. error } \\
\text { differ- } \\
\text { ence }\end{array}$} & \multicolumn{2}{|c|}{$\begin{array}{l}95 \% \text { confidence } \\
\text { interval of the } \\
\text { difference } \\
\end{array}$} & & \\
\hline & & & & & & & & & Lower & Upper & & \\
\hline & & 0.830 & 0.365 & $3.979^{*}$ & 96 & .000 & 1.000 & 0.251 & 0.501 & 1.499 & $\begin{array}{l}\text { Group I } \\
(N=49)\end{array}$ & $\begin{array}{l}2.12 \\
(+1.285)\end{array}$ \\
\hline & & & & 3.979 & 95.567 & .000 & 1.000 & 0.251 & 0.501 & 1.499 & $\begin{array}{l}\text { Group II } \\
(N=49)\end{array}$ & $\begin{array}{l}1.12 \\
(+1.201)\end{array}$ \\
\hline & & \multicolumn{5}{|c|}{$\begin{array}{l}\text { Levene's test } \\
\text { for equality of } \\
\text { variances }\end{array}$} & & & & & \multirow{3}{*}{$\begin{array}{l}\text { Group } \\
\text { statistics }\end{array}$} & \multirow{3}{*}{$\begin{array}{l}\text { Mean } \\
(S D)\end{array}$} \\
\hline & & \multirow[t]{2}{*}{$\mathrm{F}$} & \multirow[t]{2}{*}{ Sig. } & \multirow[t]{2}{*}{$\mathrm{t}$} & \multirow[t]{2}{*}{ df } & \multirow[t]{2}{*}{$\begin{array}{l}\text { Sig } \\
\text { (2-tailed) }\end{array}$} & \multirow[t]{2}{*}{$\begin{array}{l}\text { Mean } \\
\text { Diffe- } \\
\text { rence }\end{array}$} & \multirow[t]{2}{*}{$\begin{array}{l}\text { Std. error } \\
\text { difference }\end{array}$} & \multicolumn{2}{|c|}{$\begin{array}{l}95 \% \text { confidence } \\
\text { interval of the } \\
\text { difference } \\
\end{array}$} & & \\
\hline & & & & & & & & & Lower & Upper & & \\
\hline $\begin{array}{l}\text { Frankle } \\
\text { scaling rate }\end{array}$ & $\begin{array}{l}\text { Equal } \\
\text { variances } \\
\text { assumed }\end{array}$ & 0.212 & 0.646 & $-4.789^{* *}$ & 96 & 0.000 & -0.857 & 0.179 & -1.212 & -0.502 & $\begin{array}{l}\text { Group I } \\
(N=49)\end{array}$ & $\begin{array}{l}2.49 \\
(+0.916)\end{array}$ \\
\hline $\begin{array}{l}\text { (cooperation } \\
\text { level) }\end{array}$ & $\begin{array}{l}\text { equal } \\
\text { variances not } \\
\text { assumed }\end{array}$ & & & -4.789 & 95.555 & 0.000 & -0.857 & 0.179 & -1.212 & -0.502 & $\begin{array}{l}\text { Group II } \\
(N=49)\end{array}$ & $\begin{array}{l}3.35 \\
(+0.855)\end{array}$ \\
\hline
\end{tabular}

anxiety among child patients with some valid method of measurement is necessary. As each person has a limited capacity of attention, if the greater part of this attention can be caught by a distraction task, it will less be devoted to pain perception or any other anxiety-provoking situation so the anxiety will decrease. ${ }^{35}$ A number of nonpharmacological or psychological techniques aiming to manage patient behavior are present. Some approaches directed to improve the communication process, while others are proposed to eliminate inappropriate behavior or reduce anxiety. Most recommended procedures for modifying child behavior during dentistry have comprised a variety of forms of pre-exposure to the dental setting and procedures. There are techniques based on the Social Learning Theory, which accentuates the importance of observing and imitating the behaviors, attitudes, and emotional reactions of others. One such technique is Tell-Show-Do technique, where several epidemiological studies have discovered its positive effect on the reduction of dental anxiety. ${ }^{36}$ Another one is modeling technique, Bandura, ${ }^{12}$ determined that modeling or learning by observation worked not only for gaining new behaviors but also for reducing undesirable behavior. The success of modeling in reducing dental fear and anxiety has been well documented in the past; in spite of this, it has not been widely applied as a routine behavior management technique. ${ }^{37}$ This study was designed to assess the effect of audiovisual modeling distraction on anxiety and cooperation behavior in Saudi children aged 5-10 yearsold in Qassim Province during their first and second dental visits. The age group of 5 to 10 years was chosen for the present study as dental problems are difficult to treat in this age group as they reveal more disruptive behavior and dental anxiety and are extremely difficult to manage. ${ }^{38}$

In consistent with previous studies, the children in this study did not have any systemic disease and hospitalization, nor any psychiatric disorders and any psycho-pathological familial history as these variables can reinforce negative behaviors in children. ${ }^{13,39}$

Furthermore, the time and duration of appointment of both sessions for all children was set as no more than 30 minutes for each child, as it has been previously proved that children revealed more distress and uncooperative behavior when the dental procedure went beyond 30 minutes, ${ }^{40}$ and to prevent these behavior changes of the children during dental procedures, the length of the visits in the present study were no longer than 30 minutes. For further control of unanticipated influence on the study outcomes, the dental appointments were planned in the afternoon. This arrangement was prepared not only to standardize the visit time for all children but also to eliminate the chance of misbehavior due to missing the school time or the activity time if the appointments were given in the morning since these times are necessary for this age group. ${ }^{41}$ 
In the current study, children were subjected to the procedure of prophylaxis at the first visit and presented a cartoon film through a videotaped model in their second visit. Results of this study revealed that children who had been exposed to watch a video prior to their second treatment session were significantly less anxious "relaxed" and more cooperative "definitely positive to cooperation" comparing to their first dental session. These findings are in accord with that of Fields and Pinkham, ${ }^{24}$ and Rouleau et al., ${ }^{26}$ where they found that the presentation of a model through a film leads the children to demonstrate relatively little negative behavior towards dental treatment and the film presentation in addition to the procedure of prophylaxis before the film can have a positive impact on the child's acquaintance and dental behaviors. Additionally, findings of this work are in harmony with that of Melamed et al., ${ }^{23}$ where they reported that children who were prepared for restorative procedures by watching a filmed peer model harmonize with the particular elements of the treatment session were more cooperative and presented less disruptive behaviors as they experienced similar treatment procedures. During treatment, these children also received lower ratings of anxiety by independent raters and dentists in comparison with children shown an irrelevant film.

Furthermore, results of this study demonstrated that the intervention had a positive effect on the contributing children where a statistically significant difference was registered among those who watch the videos and those who did not, where children who were exposed to watching the video were significantly less anxious and more cooperative with their dentist. This finding is consistent with that of Al-Khotani et al., ${ }^{42}$ where they found that there was a marginal difference in the observed mean cooperative behavior and anxiety between those who used audiovisual distraction and those who did not. Additionally, and in agreement with this work, Filcheck et al., ${ }^{43}$ stated that the presentation of attention-grabbing videotaped material had an impact in distracting the children from the feared stimuli and that it was taken into consideration as one of the highest attractive approaches for modifying children's behavior during dental treatment.

Establishing positive memories is an important feature of the dental process for children. For this purpose, implementation of behavior management techniques from the commencement of dental treatment ${ }^{8,44,45}$ can reduce poor emotional consequences and decrease experience of pain. Recently, Rocha et al., ${ }^{46}$ emphasized the importance of distress management interventions to reduce negatively deformed memories. Anxious patients particularly may register more pain and develop a negative expectation for dental treatment in the future. ${ }^{46} \mathrm{So}$, addressing the memory of an experienced event is crucial to the coping process. ${ }^{44,47,48}$ According to the findings of the current study and for the temperament of children in all ages the use of audiovisual modeling stimulates pleasant memories and positive attitudes that will lead to less anxious and more cooperative child patient toward the dental experience.

\section{Limitations}

In the current study the sample size could be considered as a limitation, it is suggested that larger sample size and in a general clinical setting might have exposed the differences in the use of audiovisual modeling as indicated by anxiety and behavior measures. Another limitation is the exclusion of children with previous bad dental experience which might have influenced the results, this was chosen in order to achieve as a homogeneous group as possible.

\section{CONCLUSION}

Based on the findings of the current study, the presentation of audiovisual modeling in the form of a film/ video demonstrating positive, coping behavior during a dental visit is effective in reducing disruptive behavior in children who are experiencing their dental treatment represented by less anxious and more cooperative child patient. This method of preparation for the dental procedure could be implemented easily in any dental office during routine dental procedures and administered by dental auxiliaries before dental treatment.

\section{RECOMMENDATIONS}

- Future research is recommended to investigate the modeling procedure with highly phobic children and those with dental management problems, including the mentally and physically handicapped children, this can help child patient to develop a positive attitude toward oral health.

- Further investigations on the children in other age ranges are suggested including preschool age children and adolescents.

\section{REFERENCES}

1. Humphris GM, Dyer TA, Robinson PG. The modified dental anxiety scale: UK general public population norms in 2008 with further psychometrics and effects of age. BMC Oral Health. 2009;9:20. Epub 2009/08/28.

2. Davila JM, Menendez J. Relaxing effects of music in dentistry for mentally handicapped patients. Special care in dentistry : official publication of the American Association of Hospital Dentists, the Academy of Dentistry for the Handicapped, and the American Society for Geriatric Dentistry 1986;6(1):18-21. Epub 1986/01/01. 
3. Ingersoll BD, Nash DA, Gamber C. The use of contingent audiotaped material with pediatric dental patients. J Am Dent Assoc. 1984;109(5):717-719. Epub 1984/11/01.

4. Shinohara S, Nomura Y, Shingyouchi K, Takase A, Ide M, Moriyasu K, et al. Structural relationship of child behavior and its evaluation during dental treatment. Journal of oral science. 2005;47(2):91-96. Epub 2005/07/30.

5. Oliveira MM, Colares V. The relationship between dental anxiety and dental pain in children aged 18 to 59 months: a study in Recife, Pernambuco State, Brazil. Cadernos de saude publica. 2009;25(4):743-750. Epub 2009/04/07.

6. Li HC, Lopez V. Children's Emotional Manifestation Scale: development and testing. Journal of clinical nursing. 2005;14(2):223-229. Epub 2005/01/27.

7. Rayen R, Muthu MS, Chandrasekhar Rao R, Sivakumar N. Evaluation of physiological and behavioral measures in relation to dental anxiety during sequential dental visits in children. Indian journal of dental research : official publication of Indian Society for Dental Research. 2006;17(1):27-34. Epub 2006/08/12.

8. Klingberg G, Broberg AG. Dental fear/anxiety and dental behaviour management problems in children and adolescents: a review of prevalence and concomitant psychological factors. International journal of paediatric dentistry. 2007;17(6):391-406. Epub 2007/10/16.

9. Johnsen DC. Managing the Patient and Parents in Dental Practice en S.H.Y. Wei. Pediatric Dentistry:Total Patient Care Philadelphia: Lea and Febiger. 1998.

10. Pinkham JR. Behavioral themes in dentistry for children: 1968-1990. ASDC journal of dentistry for children. 1990;57(1):38-45. Epub 1990/01/01.

11. Wright GZ. Fundamentals of behavior management. En: Wright GZ, Strakey PE, Gardner DE. Managing Children's behavior in the dental office StLouis:The CV Mosby Company. 1983.

12. Bandura A, Menlove FL. Factors determining vicarious extinction of avoidance behavior through symbolic modeling. Journal of personality and social psychology. 1968;8(2):99-108. Epub 1968/02/01.

13. Wright GZ, Stigers, J.I. Nonpharmacologic management of children's behaviors. In: Dean JA, Avery DR, McDonald RE, editors Dentistry for the Child and Adolescence 9th ed St Louis: CV Mosby Co. 2011:30.

14. Melamed BG, Siegel LJ. Reduction of anxiety in children facing hospitalization and surgery by use of filmed modeling. Journal of consulting and clinical psychology. 1975;43(4):511521. Epub 1975/08/01.

15. Peterson L, Schultheis K, Ridley-Jonson R, et al. Comparison of three modeling procedures on the presurgical and postsurgical reaction of children. Behavior Therapy. 1984;15(2):197203.

16. Krouse HJ. Video modelling to educate patients. Journal of advanced nursing. 2001;33(6):748-757. Epub 2001/04/12.

17. Townsend JA. Behaviour guidance of the paediatric dental patient. In: Casa Massimo PS, Fields HW, McTigue DJ, Nowak AJ, editors Paediatric Dentistry - Infancy through Adolescence 5th ed Philadelphia: Elsevier Saunders. 2013:358.

18. Greenbaum PE, Melamed BG. Pretreatment modeling. A technique for reducing children's fear in the dental operatory. Dental clinics of North America. 1988;32(4):693-704. Epub 1988/10/01.
19. Stokes TF, Kennedy SH. Reducing child uncooperative behavior during dental treatment through modeling and reinforcement. Journal of Applied Behavior Analysis 1980;13(1):41-49. Epub 1980/01/01.

20. Farhat-McHayleh N, Harfouche A, Souaid P. Techniques for managing behaviour in pediatric dentistry: comparative study of live modelling and tell-show-do based on children's heart rates during treatment. J Can Dent Assoc 2009;75(4):283. Epub 2009/05/09.

21. Howard KE, Freeman R. An evaluation of the PALS after treatment modelling intervention to reduce dental anxiety in child dental patients. International Journal of Paediatric Dentistry 2009;19(4):233-242. Epub 2009/06/03.

22. Machen B, Johnson, R. Desensitization, model learning and the dental behaviour of children. Journal of Dental Research. 1974;53:83-86.

23. Melamed BG, Hawes RR, Heiby E, et al. Use of filmed modeling to reduce uncooperative behavior of children during dental treatment. Journal of Dental Research 1975;54(4):797801. Epub 1975/07/01.

24. Fields H, Pinkham J. Videotape modeling of the child dental patient. Journal of Dental Research 1976;55(6):958-963. Epub 1976/11/01.

25. Melamed BG, Yurcheson R, Fleece EL, et al. Effects of film modeling on the reduction of anxiety-related behaviors in individuals varying in level of previous experience in the stress situation. Journal of consulting and clinical psychology. 1978;46(6):1357-1367. Epub 1978/12/01.

26. Rouleau J, Ladouceur R, Dufour L. Pre-exposure to the first dental treatment. Journal of Dental Research 1981;60(1):30-34. Epub 1981/01/01.

27. Klingman A, Melamed BG, Cuthbert MI, et al. Effects of participant modeling on information acquisition and skill utilization. Journal of Consulting and Clinical Psychology 1984;52(3):414-422. Epub 1984/06/01.

28. Yahaya WAJ, Salam SNA. Usability design strategies for children: Developing children learning and knowledge in decreasing children dental anxiety. Proceedings of the International Conference on Primary Education, Hong Kong. 2009:Nov 25-27.

29. Mungara J, Injeti M, Joseph E, et al. Child's dental fear: cause related factors and the influence of audiovisual modeling. Journal of the Indian Society of Pedodontics and Preventive Dentistry 2013;31(4):215-220. Epub 2013/11/23.

30. Venham LL, Gaulin-Kremer E, Munster E, et al. Interval rating scales for children's dental anxiety and uncooperative behavior. Pediatric Dentistry 1980;2(3):195-202. Epub 1980/09/01.

31. Frankl S, Shiere F, Fogels H. Should the Parent Remain with the Child in the Dental Operatory? J Dent Child 1962;29:150163.

32. Venham L, Bengston D, Cipes M. Children's response to sequential dental visits. Journal of Dental Research. 1977;56(5):454-459. Epub 1977/05/01.

33. Allen KD, Stanley RT, McPherson K. Evaluation of behavior management technology dissemination in pediatric dentistry. Pediatric Dentistry 1990;12(2):79-82. Epub 1990/04/01.

34. Chu CH. Treatment of early childhood caries: a review and case report. General Dentistry 2000;48(2):142-148. Epub 2001/02/24.

35. Efron LA, Sherman JA. Five tips for managing pediatric dental anxiety. Dentistry today. 2005;24(6):104-5. Epub 2005/07/20. 
36. Klingberg G, Raadal M, Arnrup K. Dental fear and Behavior management problems. In: Koch G, Paulsen S, editors Pediatric dentistry—a clinical approach 2st ed USA: WileyBlackwell Publishing Ltd. 2009:32-43.

37. Baghdadi ZD. Principles and application of learning theory in child patient management. Quintessence Int 2001;32(2):135141. Epub 2002/06/18.

38. Ram D, Shapira J, Holan G, et al. Audiovisual video eyeglass distraction during dental treatment in children. Quintessence Int. 2010;41(8):673-679. Epub 2010/07/27.

39. Raadal M, Klingberg, G. . Behavior management problems in children and adolescents. In: Koch G, Paulsen S (eds) Pediatric Dentistry - A Clinical Approach 1st ed Munksagaard: Copenhagen. 2001:55.

40. Attar RH, Baghdadi ZD. Comparative efficacy of active and passive distraction during restorative treatment in children using an iPad versus audiovisual eyeglasses: a randomised controlled trial. European archives of paediatric dentistry : official journal of the European Academy of Paediatric Dentistry 2015;16(1):1-8. Epub 2014/11/25.

41. Pinkham JR. Pediatric dentistry: infancy through adolescence. St Louis (MO): Elsevier Saunders 2005.

42. Al-Khotani A, Bello LA, Christidis N. Effects of audiovisual distraction on children's behaviour during dental treatment: a randomized controlled clinical trial. Acta odontologica Scandinavica 2016;74(6):494-501. Epub 2016/07/14.

43. Filcheck HA, Allen KD, Ogren H, et al. The Use of ChoiceBased Distraction to Decrease the Distress of Children at the Dentist. Child Fam Behav Ther 2005;26:59-68.

44. Tsao JC, Myers CD, Craske MG, et al. Role of anticipatory anxiety and anxiety sensitivity in children's and adolescents' laboratory pain responses. Journal of Pediatric Psychology 2004;29(5):379-88. Epub 2004/06/10.

45. Sharath A, Rekka P, Muthu MS, et al. Children's behavior pattern and behavior management techniques used in a structured postgraduate dental program. Journal of the Indian Society of Pedodontics and Preventive Dentistry. 2009;27(1):22-26. Epub 2009/05/06.

46. Rocha EM, Marche TA, von Baeyer CL. Anxiety influences children's memory for procedural pain. Pain Research \& Management 2009;14(3):233-237. Epub 2009/06/24.

47. Chen E, Zelzer LK, Craske MG, et al. Alteration of memory in the reduction of children distress during medical procedures. Journal of Consulting and Clinical Psychology 1999;67:481-490.

48. Sinha M, Christopher NC, Fenn R, et al. Evaluation of nonpharmacologic methods of pain and anxiety management for laceration repair in the pediatric emergency department. Pediatrics 2006;117(4):1162-1168. Epub 2006/04/06.se 